\title{
Exogenous Application of Ethylenediaminetetraacetic Acid and Oxalic Acid Improve the Seed Germination and Enzymes Activities of Sunflower (Helianthus annuus) Under Cadmium Stress
}

\author{
Rumana Sadiq $^{1 *}$, Mumtaz Hussain ${ }^{1}$, Muhammad Ashraf ${ }^{1}$ and Khalil-ur-Rehman ${ }^{2}$ \\ ${ }^{1}$ Department of Botany, University of Agriculture, Faisalabad, Pakistan \\ ${ }^{2}$ Department of Chemistry and Biochemistry, University of Agriculture, Faisalabad, Pakistan \\ *For Correspondence: sadiqrumana@yahoo.com
}

\begin{abstract}
The study was conducted to examine the deleterious effects of cadmium $(\mathrm{Cd})$ on metabolic enzymes and their end products during seed germination and the effect of ethylenediaminetetraacetic acid (EDTA) and oxalic acid (OA) in easing the Cd toxicity in two sunflower hybrids (Hysun-33 and FH-533). To accomplish this, a pot experiment was carried out in small sandfilled plastic pots under normal environment temperature $\left(28 \pm 2^{\circ} \mathrm{C}\right)$. Seeds of both sunflower hybrids were exposed to Cd levels $(250$ and $450 \mathrm{mg} / \mathrm{kg}$ ) alone and in combination of optimized level of chelating agents EDTA and OA (each at the rate of $1 \mathrm{~g} / \mathrm{kg}$ ) at the time of sowing. The enzymes activities of two germinating hybrids were recorded over time from 24 to $120 \mathrm{~h}$ after sowing. When $\mathrm{Cd}$ was applied alone it reduced the germination rate, enzymes activities and total soluble sugars contents. Mobilization of stored proteins and amino acids were also suppressed in germinating seeds of both hybrids. However, application of EDTA and OA in combination with $\mathrm{Cd}$ improved the germination rate of seeds by surpassing the biochemical metabolism and enhanced the activities of $\alpha$-amylase and protease revealing the ameliorating effect to Cd toxicity. Results revealed that minimum values of all the attributes are obtained at $450 \mathrm{mg} / \mathrm{kg}$ of Cd level, while chelators treatments proved effective in relieving $\mathrm{Cd}$ stress of which OA had $10 \%$ more pronounced germination percentage than EDTA and $30 \%$ more as compared to control. Interactive studies showed that both the chelators detoxify the $250 \mathrm{mg} / \mathrm{kg}$ of Cd more as compared to 450 $\mathrm{mg} / \mathrm{kg}$ of Cd. Results clearly indicated that sunflower hybrid Hysun-33 showed greater activities of two hydrolyzing enzymes and efficient mobilization of reserved sugars and proteins than hybrid FH-533 under Cd stress, so it can be grown on Cd contaminated soils for higher plant productivity. Thereafter EDTA and OA could be supportive to improve the seed germination security in Cd polluted soil. (C) 2015 Friends Science Publishers
\end{abstract}

Keywords: Helianthus annuus; Cd stress; Chelator; $\alpha$-amylase; protease

\section{Introduction}

Industry flourishes analogous to urbanization but augmented industrialization produced industrial waste especially metallic elements which are harmful for the environment (Wei and Yang, 2010; Yaylal1-Abanuz, 2011; Mireles et al., 2012). Among metallic elements $\mathrm{Cd}$ is a potential pollutant which penetrates in agricultural soil through irrigation with industrial effluents, application of sewage sludge, pesticides and commercial fertilizers (Wu et al., 2004; Kidd et al., 2007; Papafilippaki et al., 2007; Grant and Sheppard, 2008; Cotuk et al., 2010) and contaminate the soil resulting in its amassing in different plant parts (Cheng et al., 2006). Plants accumulate the $\mathrm{Cd}$ in edible parts as being primary producer of the food chain and thus serve as a main source of intake in animals and humans (Wahid and Ghani, 2008; Pinot et al., 2000; Lopez-Millan et al., 2009).
Incorporation of the $\mathrm{Cd}$ takes place in plants through nonspecific pathways. Owing to inordinate solubility and toxicity of $\mathrm{Cd}$; it exerts deleterious effects on growth leading to plant death (Pinto et al., 2004). Higher Cd concentration generates oxidative stress indirectly by reticence of the photoactivation process in chloroplasts resulting in free radicals formation that may impair the tissues of plants (Heyno et al., 2008). It also effects the gas exchange parameters, diminish the chlorophyll contents and disrupts the plant water relations (Singh and Tewari, 2003; Vijayaragavan et al., 2011). The literature presents that higher $\mathrm{Cd}$ levels adversely affect the metabolic activities of germinating seeds resulting in impaired germination and reduced plant growth. $\alpha$-amylase enzyme is responsible for conversion of starch into sugars (Junyu et al., 2008) and protease is responsible for conversion of proteins into amino acids (Kranner and Colville, 2011) Cd inactivates the

To cite this paper: Sadiq, R., M. Hussain, M. Ashraf and K.U. Rehman, 2015. Exogenous application of ethylenediaminetetraacetic acid and oxalic acid improve the seed germination and enzymes activities of sunflower (Helianthus annuus) under cadmium stress. Int. J. Agric. Biol., 17: 1117-1124 
enzymes by reacting with their SH- group (Ramon et al., 2003) therefore, both are susceptible to Cd stress.

The Chelators, organic or inorganic agents are being widely used for metals mobilization to rehabilitate the metal contaminated soils by plants (Madrid et al., 2003; Chen et al., 2014), they form the water soluble complexes with metal ions and desorb them from various soil components (Sun, 2009). Although the chelators effectiveness is well reported for phytoremediation, but their effect on plants growth and development and various physiological and biochemical processes has not been inspected in depth. EDTA, a well-known synthetic chelator, is one of the successful and admired chemical regents because of its strong affinity for Cd (Saifullah et al., 2009). It is a powerful, recoverable and comparatively biostable chelator which has the ability to remediate the metal affected soils (Meers et al., 2005). EDTA promotes the Cd solubility as it has definite affinity and binding ability with $\mathrm{Cd}$, but it did not enhances the $\mathrm{Cd}$ uptake in plants and consequently ameliorate its toxic effect (Romkens et al., 2002). However, most synthetic chelators like EDTA and EDDS form complexes with metals which have high stability and contaminate the groundwater (Zeremski-Skoric et al., 2010). Low-molecular-weight organic acids (LMWOA) like oxalic acid (OA) and citric acid (CA) may prove environmentally compatible alternatives for synthetic chelators because they are the part of root exudates thus acting as natural chelators (Hsiao et al., 2007). Natural chelators affect the sorption and desorption of $\mathrm{Cd}$ as they have strong tendencies to bind with metals (Nigam et al., 2001). They form complexes with $\mathrm{Cd}$ ranging from low to moderate constancy (Evangelou et al., 2006) and present a benefit over synthetic chelators because of their high biodegradation rate in soil (Quartacci et al., 2005).

Worldwide sunflower is one of the major promising edible oil seed crops (Taran et al., 2013). During 2011 the area under sunflower cultivation in Pakistan was 877 hectares, which fulfilled the 179 tons oil demand in the country (Govt. of Pakistan, 2012). Sunflower being a most competent deep rooted crop with fast growing rate (Prasad, 2004) high biomass production (Zhuang et al., 2005) and metal tolerance potential is being cultivated on heavily metal contaminated areas (Jadia and Fulekar, 2008). Keeping in view the deleterious effects of $\mathrm{Cd}$ on seed germination this investigation was conducted under the hypothesis that "addition of EDTA and OA in the $\mathrm{Cd}$ contaminated growth medium improves seed germination of sunflower by enhancing $\alpha$-amylase and protease activities and their resulting products".

\section{Materials and Methods}

The experiment was conducted under natural environmental conditions of light and temperature $\left(28 \pm 2^{\circ} \mathrm{C}\right)$ in the wire house of Dept. of Botany, University of Agriculture, Faisalabad. Seeds of sunflower hybrids Hysun-33 and FH-
533 were obtained from Ayub Agricultural Research Institute (AARI). Experiment was laid down in a completely randomized design having three replicates with factorial arrangement. Twenty seeds were sown in each plastic pot containing $1 / 2 \mathrm{~kg}$ of acid and distilled water washed sand. From preliminary screening experiments three levels of $\mathrm{Cd}$ (control, 250 and $450 \mathrm{mg} / \mathrm{kg}$ ) and two levels of EDTA and OA (control and $1 \mathrm{~g} / \mathrm{kg}$ ) were selected for sunflower, a promising crop for environment industry having appreciable tolerance level against metals (Sadiq, 2014). These treatments were applied once separately and in combination on both hybrids at the time of sowing. The seeds were allowed to grow for one week under natural conditions. Germination was recorded after $120 \mathrm{~h}$ of seed sowing. The $\alpha$-amylase and protease activities and sugars, proteins and amino acids contents were determined in the germinating seeds after 24, 48, 72, 96 and $120 \mathrm{~h}$ of sowing. The activity of $\alpha$-amylase enzyme was determined by using the method of (Chrispeels and Varner, 1967), while the protease activity followed the method of (Ainouz, 1970). Sugars were estimated according to the method of (Riazi et al., 1985), total soluble proteins by following the protocol as described by (Lowry et al., 1951) and total free amino acids by the procedure of (Hamilton and Van-Slyke, 1943).

\section{Statistical Analysis}

The data was statistically analyzed using COSTAT computer package (CoHort Software, 2003, Monterey, California). Analysis of variance (ANOVA) was performed and least-significant difference (LSD) test was used for comparison of means (Steel and Torrie, 1986).

\section{Results}

\section{Germination Rate (\%)}

Cd exerted significant $(\mathrm{p}<0.05)$ effect on germination rate of two sunflower hybrids. The maximum germination rate was observed in seedlings under control conditions followed by both chelators i.e., OA and EDTA, combination of both chelators with lower dose of Cd i.e., $250 \mathrm{mg} \mathrm{Cd} / \mathrm{kg}+1 \mathrm{~g}$ $\mathrm{OA} / \mathrm{kg}$ and $250 \mathrm{mg} \mathrm{Cd} / \mathrm{kg}+1 \mathrm{~g}$ EDTA/kg, combined application of both chelators with higher $\mathrm{Cd}$ level i.e. 450 $\mathrm{mg} \mathrm{Cd} / \mathrm{kg}+1 \mathrm{~g} \mathrm{OA} / \mathrm{kg}$ and $450 \mathrm{mg} \mathrm{Cd} / \mathrm{kg}+1 \mathrm{~g}$ EDTA/kg and then lower and higher levels of Cd (Fig. 1a, b). Both hybrids followed the similar trend but FH-533 experienced more reduction in germination rate under all treatments than Hysun-33.

\section{Alpha Amylase and Sugars}

Imposition of $\mathrm{Cd}$ had pronounced effect on $\alpha$-amylase activity. Generally the enzyme activity increased with the passage of time i.e., 24, 48, 72, 96 and $120 \mathrm{~h}$ after seed sowing. While in term of treatments the maximum activity 
Exogenous Use of EDTA in Reducing the Cd Toxicity on Sunflower / Int. J. Agric. Biol., Vol. 17, No. 6, 2015

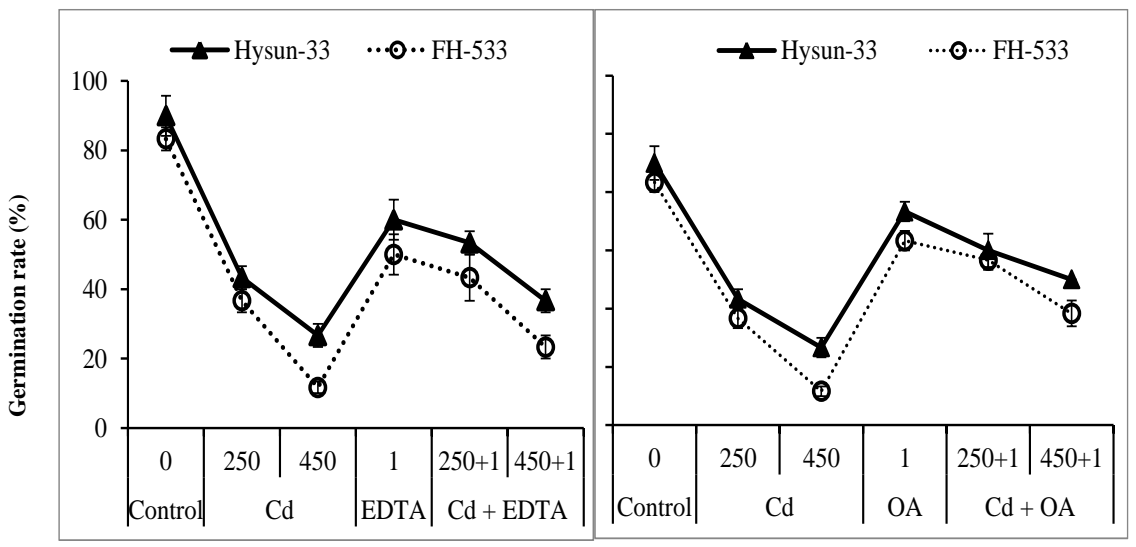

Fig. 1: Germination rate of two sunflower hybrids under $\mathrm{Cd}(\mathrm{mg} / \mathrm{kg})$, EDTA $(\mathrm{g} / \mathrm{kg})$ and $\mathrm{OA}(\mathrm{g} / \mathrm{kg})$ application. Error bars are shown

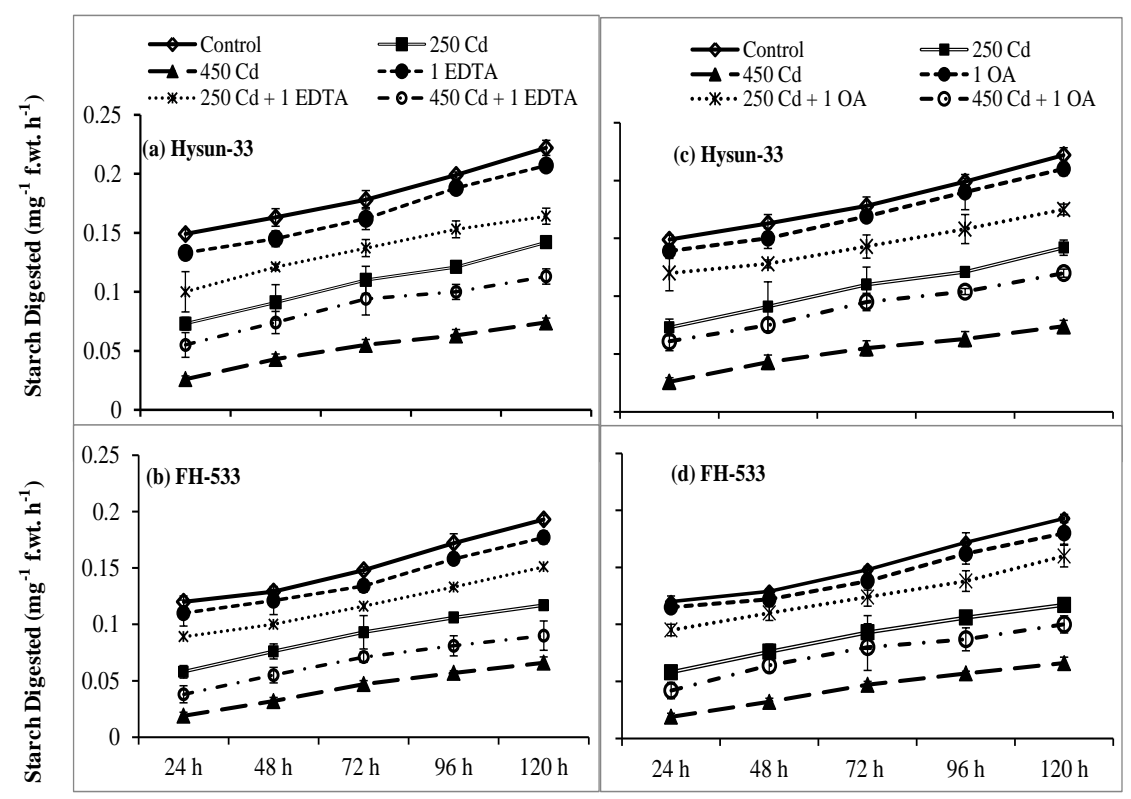

Fig. 2: Effect of $\mathrm{Cd}(\mathrm{mg} / \mathrm{kg})$ on $\alpha$-amylase activity of two sunflower hybrids under the influence of EDTA $(\mathrm{g} / \mathrm{kg})(\mathrm{a}, \mathrm{b})$ and $\mathrm{OA}(\mathrm{g} / \mathrm{kg})(\mathrm{c}, \mathrm{d})$. Error bars are shown

was recorded in plants under controlled condition $(0 \mathrm{mg}$ $\mathrm{Cd} / \mathrm{kg}+0 \mathrm{~g}$ EDTA $/ \mathrm{kg}$ ) and minimum activity was observed in plants treated with $450 \mathrm{mg} \mathrm{Cd} / \mathrm{kg}$, while other treatments laid in between them i.e., $1 \mathrm{~g} \mathrm{EDTA} / \mathrm{kg}, 250 \mathrm{mg} \mathrm{Cd} / \mathrm{kg}+1$ $\mathrm{g}$ EDTA/kg, $250 \mathrm{mg} \mathrm{Cd} / \mathrm{kg}, 450 \mathrm{mg} \mathrm{Cd} / \mathrm{kg}+1 \mathrm{~g}$ EDTA $/ \mathrm{g}$ (Fig. 2a, b). OA application in the presence and absence of $\mathrm{Cd}$ also followed the same trend but it proved more effective in ameliorating the toxic effects of $\mathrm{Cd}$ on alphaamylase activity of germinating seeds than EDTA (Fig. 2b, c). Hysun-33 had greater activity of alpha-amylase as compared to FH-533. The reduction in $\alpha$-amylase activity appeared to have straight inhibitory influence on starch hydrolysis, resulting in reduced sugars formation. Overall the concentration of sugars persistently increased in both hybrids over time, which was highest at $120 \mathrm{~h}$ after sowing (Fig. 3a, b, c, d).

\section{Protease, Proteins and Amino Acids}

The application of $\mathrm{Cd}$ expressively inhibited the protease activity hence the stored proteins conversion into amino acids. The maximum enzyme activity in term of treatment was recorded in control plants followed by $1 \mathrm{~g} \mathrm{EDTA} / \mathrm{kg}$, $250 \mathrm{mg} \mathrm{Cd} / \mathrm{kg}+1 \mathrm{~g} \mathrm{EDTA} / \mathrm{kg}, 250 \mathrm{mg} \mathrm{Cd} / \mathrm{kg}, 450 \mathrm{mg}$ $\mathrm{Cd} / \mathrm{kg}+1 \mathrm{~g} \mathrm{EDTA} / \mathrm{kg}$ and $450 \mathrm{mg} \mathrm{Cd} / \mathrm{kg}$ treated plants (Fig. 4a, b). Same is the case with OA application i.e., control was followed by $1 \mathrm{~g} \mathrm{OA} / \mathrm{kg}$, OA application in combination with metal exerted less suppressing effects on protease activity than separate application of Cd (Fig. 4c, d). Protease activity increased with the passage of time under the influence of all treatments in selected sunflower hybrids. Generally after $48 \mathrm{~h}$ of treatment application, the proteolytic 
Sadiq et al. /Int. J. Agric. Biol., Vol. 17, No. 6, 2015

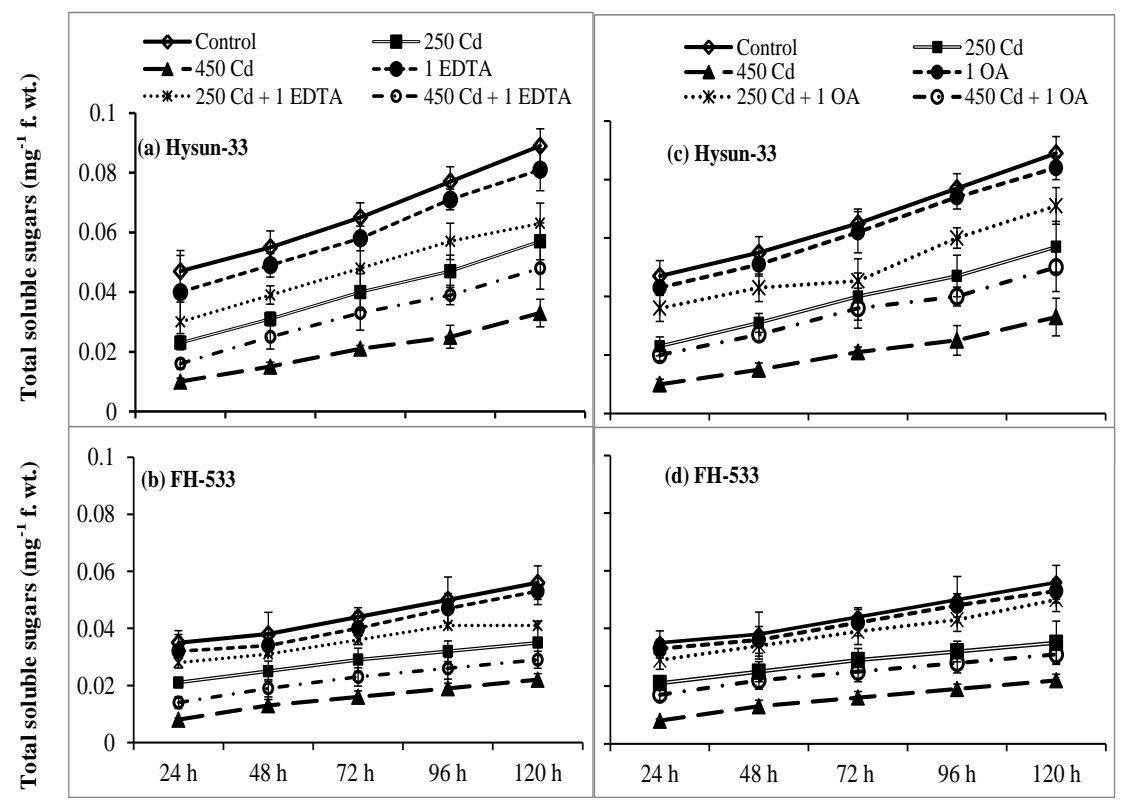

Fig. 3: Effect of $\mathrm{Cd}(\mathrm{mg} / \mathrm{kg})$ on total soluble sugars of two sunflower hybrids under the influence of EDTA $(\mathrm{g} / \mathrm{kg})(\mathrm{a}, \mathrm{b})$ and $\mathrm{OA}(\mathrm{g} / \mathrm{kg})(\mathrm{c}, \mathrm{d})$. Error bars are shown

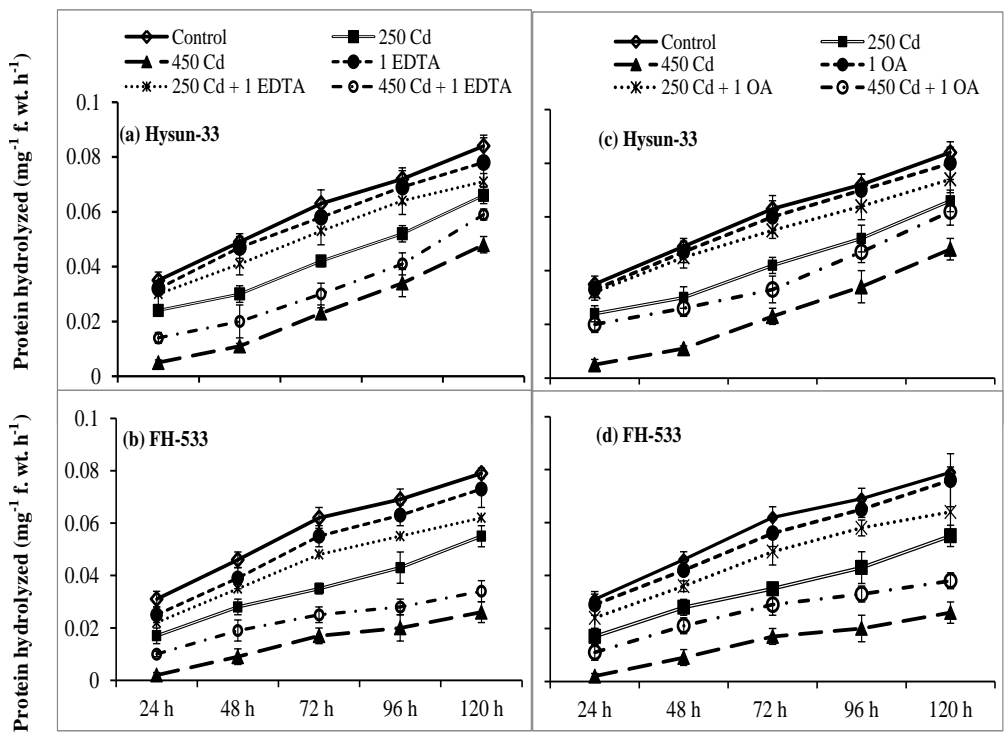

Fig. 4: Effect of $\mathrm{Cd}(\mathrm{mg} / \mathrm{kg})$ on protease activity of two sunflower hybrids under the influence of EDTA $(\mathrm{g} / \mathrm{kg})(\mathrm{a}, \mathrm{b})$ and $\mathrm{OA}(\mathrm{g} / \mathrm{kg})(\mathrm{c}, \mathrm{d})$. Error bars are shown

activity displayed a steep increase and at 120th $\mathrm{h}$ reached the maximum value. Seedlings of sensitive hybrid FH533 contained more protein contents than tolerant Hysun33 under all tested treatments during all time intervals. The lower protease activity in germinating seeds of $\mathrm{FH}$ 533 was evident from its higher protein contents (Fig. 5b, d). The amino acids contents increased the activity of protease in both hybrids under all treatments (Fig. 6a, b, c, d). The amino acids contents also increased over the passage of time and reached the highest value at $120^{\text {th }} \mathrm{h}$.

\section{Discussion}

Germination ability of seed is a useful parameter for the decision of tolerance level as it is the first interface for material exchange between plant development and soil environment (Rahoui et al., 2010). Some previous studies have proved that higher $\mathrm{Cd}$ levels imposed adverse effect on seed germination resulted in retarded plant growth (Shafiq et al., 2008; Aydinalp and Marinova, 2009; Zhang et al., 2012) as in alfalfa seeds (Peralta et al., 2001). Cd 
Exogenous Use of EDTA in Reducing the Cd Toxicity on Sunflower / Int. J. Agric. Biol., Vol. 17, No. 6, 2015

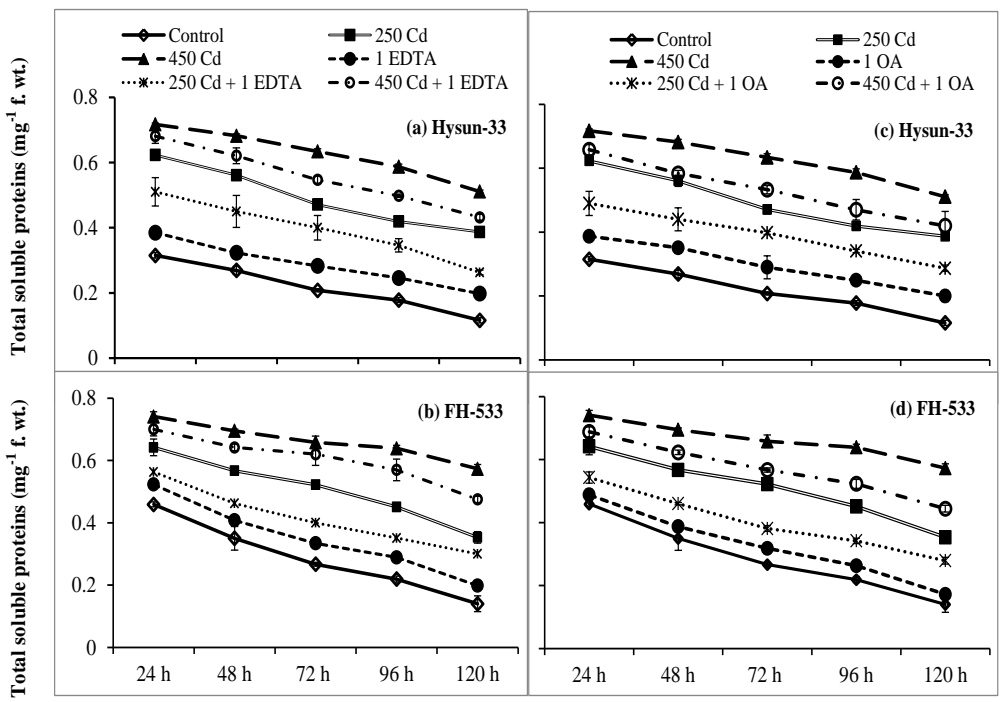

Fig. 5: Effect of $\mathrm{Cd}(\mathrm{mg} / \mathrm{kg})$ on total soluble proteins of two sunflower hybrids under the influence of EDTA $(\mathrm{g} / \mathrm{kg})(\mathrm{a}, \mathrm{b})$ and $\mathrm{OA}(\mathrm{g} / \mathrm{kg})(\mathrm{c}, \mathrm{d})$. Error bars are shown

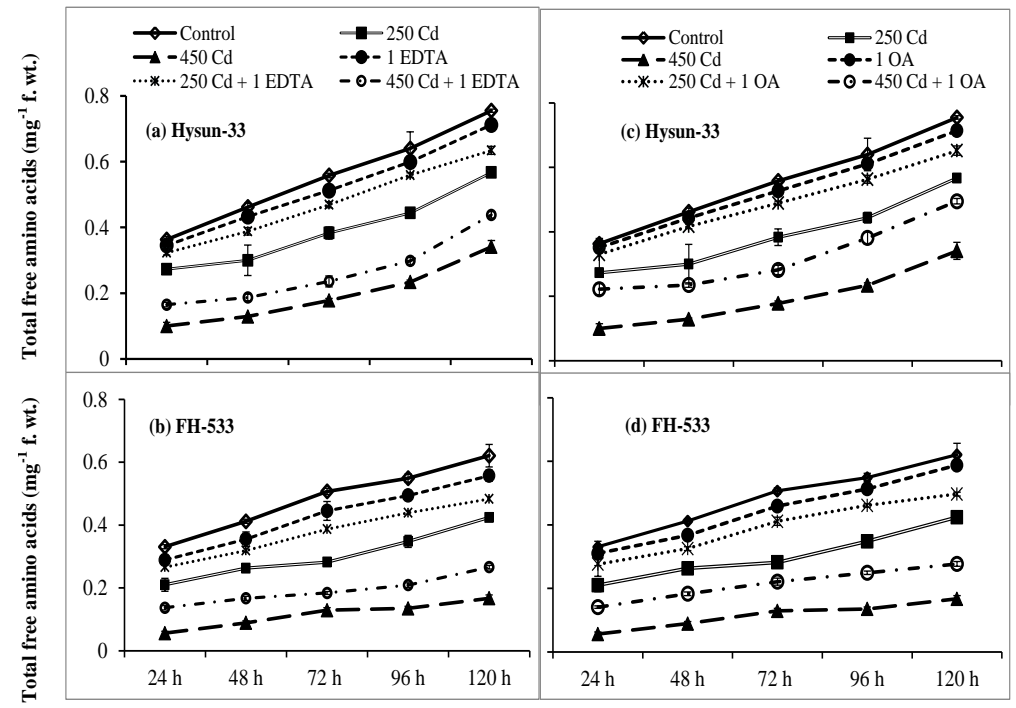

Fig. 6: Effect of $\mathrm{Cd}(\mathrm{mg} / \mathrm{kg})$ on total free amino acids of two sunflower hybrids under the influence of EDTA $(\mathrm{g} / \mathrm{kg})(\mathrm{a}, \mathrm{b})$ and $\mathrm{OA}(\mathrm{g} / \mathrm{kg})(\mathrm{c}, \mathrm{d})$. Error bars are shown

interference changes the permeability of cell membrane which lessened absorption and transport of water as well as reduced the stress tolerance potential during germination (Russak et al., 2008). The results included in Fig. 1 (a, b) show that $\mathrm{Cd}$ induced significant decline in germination rate of both sunflower hybrids i.e., Hysun-33 and FH-533. However, addition of chelating agents in $\mathrm{Cd}$ containing growth medium assisted in removing the toxic effect of $\mathrm{Cd}$ on seed germination. Chelating substances prevent the entry of metal ions across the seed coat by engulfing them and forming stable EDTA-Cd and OA-Cd complexes (Mejre and Bulow, 2001; Mohanty and Patra, 2011). Imbibition of seed activates hydrolytic enzymes during the germination process (Sreenivasulu et al., 2008) and these are inactivated or suppressed by the metal stress as in Fig 2 (a, b, c, d). Hydrolytic enzymes make the availability of reserve materials that deliver fuel for respiration and various anabolic reactions in the form of metabolites. Enzymes of starch and protein digestion i.e., $\alpha, \beta$-amylase and protease are accountable for breakdown and mobilization of these major reserve materials of seeds (Alencar et al., 2012). The maximum retarded activity of enzymes was observed when Cd was applied @ $450 \mathrm{mg} / \mathrm{kg}$ while both the chelators especially OA helped in relieving the toxic effects of $\mathrm{Cd}$ on both hydrolytic enzymes. These results coincide with work on chickpea reported by Mondal et al. (2013). The major 
starch hydrolysing enzymes of seeds endosperm are $\alpha$ amylase, starch phosphorylase and $\alpha$-glucosidase, (Zhu et al., 1998). Among them, $\alpha$-amylase is most crucial one, as it is responsible for breakdown of $\alpha-(1-4)$ linkages of starch and converts it to either amylopectin or amylose by random hydrolysis of polymer. Thus various micromolecules having low molecular weight and short chains known as dextrins are generated from these macromolecules. Reduction of $\alpha$ amylase activity in both germinating hybrid seeds under $\mathrm{Cd}$ stress occurred as compared to control i.e., untreated seeds. However, with passage of time the overall $\alpha$-amylase activity was augmented, indicating that $\mathrm{Cd}$ stress directly affected the enzyme activity available to fulfil the least requirements of developing shoot apices in phase of early growth (Fig. 2a, b, c, d). Impaired carbohydrates mobilization due to disturbed $\alpha$-amylase activity under $\mathrm{Cd}$ was reported in oregano (Farashah et al., 2011), pea (Mihoub et al., 2005; Smiri, 2011), wheat (Amirjani, 2012) and bean seeds (Sfaxi-Bousbih et al., 2010). Under Cd stress the concentration of total soluble sugars increased with incubation time. However, the elevation in sugars concentration was significantly lower than control for all treatments of metal either with or without chelators (Fig. 3a, b, c, d). Veer (1989) reported same results for sugar contents of seeds germinating under Cd stress. However, Loreti et al. (2003) reported that maintaining high sugar contents by cereal grains at germination time was the result of minor effect of stress on activity of $\alpha$-amylase. Contrary, the present results indicated the activation of hydrolytic activity of enzyme in germinating seeds of both sunflower hybrids which was meaningfully delayed under different treatments of Cd. Enzymes such as $\alpha$ and $\beta$ amylase, starch phosphorylase and starch invertase are responsible for carbohydrate metabolism in seeds (Yang et al., 2001; Ende et al., 2002). Presence of high concentrations of various metals in soil either essential or non-essential causes a significant perturbation in carbohydrates (Jha and Dubey, 2005). As a result of this direct influence on activity of metabolic enzymes of germinating seeds, the level of vital biomolecules including sugars, proteins, amino acids and nucleotides is altered (Subedi and Bhattarai, 2003). Another enzyme, protease is thought to participate in various physiological as well as metabolic process of plants related to protein turnover. This, as a result regulate various stress responses such as senescence, defence responses, abiotic stress and programmed cell death (Fontanini and Jones, 2002; Segarra et al., 2002; Roberts et al., 2003; Coffeen and Wolpert, 2004). For example, Balestrasse et al. (2003) reported suppressed protease activity in $\mathrm{Cd}$ stressed nodules of soybean roots. Some previous findings also proved reduced activity of protease in duckweed and rice when treated with high doses of $\mathrm{Cd}$ and $\mathrm{Pb}$ respectively (Sethy and Ghosh, 2013). Some reports have shown that interaction of metal ions with $\mathrm{S}, \mathrm{O}$ and $\mathrm{N}$ ligands of enzymes active groups is the main cause of inhibition of enzyme activities (Bavi et al., 2011). Fig. 4 (a, b, c, d) showed that protease activity was markedly affected under all $\mathrm{Cd}$ treatments i.e., with and without chelators. A notable decrease in protein contents was observed with the increase in seedlings age. Protein contents were also decreased with the increasing concentration of $\mathrm{Cd}$ in growth medium, which was less for treatments having chelating agents either OA or EDTA (Fig. 5a, b, c, d). Zeid (2001) also reported high protein contents under metal stress, while chelating agents helped in reducing the toxic effects of metals on proteins and their hydrolysing enzyme by limiting the metal availability to germinating seeds. Germinating seeds obtain amino acids by the hydrolysis of stored proteins. The protein hydrolysis and succeeding amino acids conversion in germinating seeds are accurately maintained to fulfil the requirements of new proteins biosynthesis and some other biomolecules as well, including apices growth controlling enzymes (Bewley, 2001). Total free amino acids levels were elevated gradually with passage of time, while declined with different $\mathrm{Cd}$ treatments in growth medium (Fig. 6a, b, c, d). High Cd levels disturbed the stored protein hydrolysis and resulted in reduced amino acids pool (Mihoub et al., 2005; Rahoui et al., 2010). The results presented here indicated that although chelators played their role in relieving $\mathrm{Cd}$ stress but significant decrease in protein hydrolysis and its conversion into amino acids under $\mathrm{Cd}$ stress was the direct outcome of $\mathrm{Cd}$ induced suppression of protease activity. Activation of ribonucleolytic and proteolytic enzymes is also essential for seedling development (Rahman et al., 2008). They participate in seed germination process by regulating RNA turnover and mobilization of food from storage tissues in seeds (Wang et al., 2007). RNases and proteases activity is essential for breakdown of protein, their recycling and amino acids mobilization towards the growing embryo in seeds (Palma et al., 2002; Yamauchi, 2003). Disturbed activity of both these enzymes under metal stress resulted in altered protein and amino acids levels in germinating seeds (Maheshwari and Dubey, 2008). The two chelators- natural (Oxalic acid) and synthetic (EDTA) relieve the stress on $\alpha$ amylase and protease activity by subdue the availability of $\mathrm{Cd}$ ions in growth medium, consequently the activity of both the enzymes was not severely affected (Zeid, 2001).

\section{Conclusion}

It is concluded that the seed germination is noticeably reduced by $\mathrm{Cd}$ toxicity due to reduced activities of key hydrolyzing enzymes $\alpha$-amylase and protease. EDTA and OA application alone caused slight reduction in seed germination and on enzymes activity as compared to control exhibit the protective effects of both chelators against $\mathrm{Cd}$ noxiousness that might be credited to the reticence/curtailment of $\mathrm{Cd}$ uptake in seeds. The EDTA and OA addition in $\mathrm{Cd}$ contaminated growth medium upgraded these parameters proving the stress ameliorating potential of chelators to $\mathrm{Cd}$ toxicity. However OA proved more effective than EDTA, therefore, its application is suggested for $\mathrm{Cd}$ contaminated mediums/soils. 


\section{References}

Ainouz, I.I., 1970. Preliminary studies on proteins of Vigna sinesis. Acid. Bvas. Ciemms., 42: 97-101

Alencar, N.L.M., R. Innecco, E. G-Filho, M.I. Gallao, J.C. A-Pizarro, J.T. Prisco and A.B. De Oliveira, 2012. Seed reserve composition and mobilization during germination and early seedling extablishment of Cereus jamacaru D.C. ssp. Jamacaru (Cactaceae). Ann. Acad. Bras. Cienc, 84: 823-832

Amirjani, M.R., 2012. Effects of cadmium on wheat growth and some physiological factors. Poll. Int. J. For. Soil Erosion, 1: 50-58

Aydinalp, C. and S. Marinova, 2009. The effects of heavy metals on seed germination and plant growth on alfalfa plant (Medicago sativa) Bulg. J. Agri. Sci., 15: 347-350

Balestrasse, K.B., M.P. Benavides, S.M. Gallego and M.L. Tomoro, 2003. Effect of cadmium stress on nitrogen metabolism in nodules and roots of soybean plants. Funct. Plant Biol., 30: 57-64

Bavi, K., B. Kholdebarin and A. Moradshahi, 2011. Effect of cadmium growth, protein content and peroxidase activity in pea plants. Pak. $J$. Bot., 43: 1467-1470

Bewley, J.D., 2001. Seed germination and reserve mobilization. Encyclopedia Life Sci., 1-7

Chen, M., L. Cao, X. Song, X. Wang, Q. Qian and W. Liu, 2014. Effect of iron plaque and selenium on cadmium uptake and translocation in rice seedlings (Oryza sativa) grown in solution culture. Int. J. Agric. Biol., 16: 1159-1164

Cheng, F.M., N.C. Zhao, H.M. Xu, Y. Li, W.F. Zhang, Z.W. Zhu and M.X. Chen, 2006. Cadmium and lead contamination in japonica rice grains and its variation among the different locations in southeast China. Sci. Total Environ., 359: 156-166

Chrispeels, M.J. and K.E. Varner, 1967. Gibberellic acid-enhanced synthesis and release of alpha-amylase and ribonuclease by isolated barley and aleurone layers. Plant Physiol., 42: 398-406

Coffeen, W.C. and T.J. Wolpert, 2004. Purification and characterization of serine proteases that exhibit caspase-like activity and are associated with programmed cell death in Avena sativa. Plant Cell, 16: 857-873

Cotuk, Y., M. Belivermis and O. Kilic, 2010. Envionmental biology and pathophysiology of cadmium. IUFS J. Biol., 69: 1-5

Ende, W.V.D., A. Michiels, K. Le Roy and A. Van Laere, 2002. Cloning of a vacuolar invertase from Belgian endive leaves (Cichorium intybus). Physiol. Plant., 115: 504-512

Evangelou, M.W.H., M. Ebel and A. Schaeffer, 2006. Evaluation of the effect of small organic acids on phytoextraction of $\mathrm{Cu}$ and $\mathrm{Pb}$ from soil with tobacco Nicotiana tabacum. Chemosphere, 63: 996-1004

Farashah, H.D., R.T. Afshari, F. Sharifzadeh and S. Chavoshinasab, 2011 Germination improvement and $\alpha$-amaylase and $\beta-1,3$-glucanase activity in dormant and non-dormant seeds of Oregano (Origanum vulgare). Aust. J. Crop Sci., 5: 421-427

Fontanini, D. and B.L. Jones, 2002. SEP-1 a subtilisin-like serine endopeptidase from germinated seeds of Hordeum vulgare $\mathrm{L} \mathrm{cv}$. Morex. Planta, 215: 885-893

Govt. of Pakistan, 2012. Pakistan Economic Survey 2011-12. Econ. Advisor's Wing, Finance Div., Islamabad, Pakistan

Grant,C.A. and S.C. Sheppard, 2008. Fertilizer impacts on cadmium availability in agricultural soils and crops. Hum. Ecol. Risk Assess., 14: 210-228

Hamilton, P.B. and D.D. Van-Slyke, 1943. Amino acid determination with ninhydrin. J. Biol. Chem., 150: 231-233

Heyno, E., C. Klose and A. Krieger-Liszkay, 2008. Origin of cadmiuminduced reactive oxygen species production: mitochondrial electron transfer versus plasma membrane NADPH oxidase. New Phytol., 179: 687-699

Hsiao, K.H., P.H. Kao and Z.Y. Hseu, 2007. Effects of chelators on chromium and nickel uptake by Brassica juncea on serpentine-mine tailings for phytoextraction. J. Hazard. Mater., 148: 366-376

Jadia, C.D. and M.H. Fulekar, 2008. Phytoremediation: The application of vermicompost to remove zinc, cadmium, copper, nickel and lead by sunflower plant. Environ. Eng. Manage. J., 7: 547-558

Jha, A.B. and R.S. Dubey, 2005. Effect of arsenic on behaviour of enzymes of sugar metabolism in germinating rice seeds. Acta Physiol. Plan., 27: $341-347$
Junyu, H., R. Yan-fang, Z. Cheng and J. De-an, 2008. Effects of cadmium stress on seed germination, seedling growth and seed amylase activities in rice (Oryza sativa). Rice Sci., 15: 319-325

Kidd, P.S., D.M. Dominguez-Rodriguez and C. Monterroso, 2007. Bioavailability and plant accumulation of heavy metals and phosphorus in agricultural soils amended by long term application of sewage sludge. Chemosphere, 66: 1458-1467

Kranner, I. and L. Colville, 2011. Metals and seeds: biochemical and molecular implications and their significance for seed germination. Environ. Exp. Bot., 72: 93-105

Lopez-Millan, A., R. Sagardoy, M. Solanas, A. Abadia and J. Abadia, 2009. Cadmium toxicity in tomato (Lycopersicum esculentum) plants grown in hydroponics. Environ. Exp. Bot., 65: 376-385

Loreti, E., J. Yamaguchi, A. Alpi and P. Perata, 2003. Sugar modulation of $\alpha$-amylase genes under anoxia. Ann. Bot., 91: 143-148

Lowry, O.H., N.J. Roebrough, R.J. Randall and A.L. Farr, 1951. Protein measurement with Folin phenol reagent. J. Biol. Chem., 193: 265-275

Madrid, F., M.S. Liphadzi and M.B. Kirkham, 2003. Heavy metal displacement in chelate-irrigated soil during phytoremediation. $J$. Hydrology, 271: 107-119

Maheshwari, R. and R. Dubey, 2008. Inhibition of ribonuclease and protease activities in germinating rice seeds exposed to nickel. Acta Physiol. Plant., 30: 863-872

Meers, E., A. Ruttens, M.J. Hopgood, D. Samson and F.M.G. Tack, 2005. Comparison of EDTA and EDDS as potential soil amendments for enhanced phytoextraction of heavy metals. Chemosphere, 58: 1011-1022

Mejre, M.A. and J.K. Bulow, 2001. Chelation strategy in heavy metal resistance of plants. Special isue. Environmental contamination, toxicology and health. Chemosphere, 41: 197-207

Mihoub, A., A. Chaoui and E. El-Ferjani, 2005. Biochemical changes associated with cadmium and copper stress in germinating pea seeds (Pisum sativum L.). C.R. Biol., 328: 33-41

Mireles, F., J.I. Davila, J.L. Pinedo, E. Reyes, R.J. Speakman and M.D. Glascock, 2012. Assessing urban soil pollution in the cities of Zacatecas and Guadalupe, Mexico by instrumental neutron activation analysis. Microchem. J., 103: 158-164

Mohanty, M. and H.K. Patra, 2011. Efect of $\mathrm{Cr}^{+6}$ and chelating agents on growth, pigment status, proline content and chromium bioavailability in rice seedlings. Int. J. Biotechnol. App., 3: 91-96

Mondal, N.K., C. Das, S. Roy, J.K. Datta and A. Banerjee, 2013. Effect of varying $\mathrm{Cd}$ stress on Chickpea (Cicer arietinum L.) seedlings: an ultrastructural study. Ann. Environ. Sci., 7: 59-70

Nigam, R., S. Srivastava, S. Prakash and M.M. Srivastava, 2001. Cadmium mobilization and plant availability- the impact of organic acids commonly exuded from roots. Plant Soil, 230: 107-113

Palma, J.M., L.M. Sandalio, F.J. Corpas, M.C. Romero-Puertas, I. McCarthy and L.A. del Rio, 2002. Plant protease, protein degradation, and oxidative stress: Role of peroxisomes. Plant Physiol. Biochem., 40: 521-530

Papafilippaki, A., D. Gasparatos, C. Haidouti and G. Stavroulakis, 2007. Total and bioavailable forms of $\mathrm{Cu}, \mathrm{Zn}, \mathrm{Pb}$ and $\mathrm{Cr}$. In agricultural soils. A study from the hydrological basin of Keritis, Chania, Greece. Global Nest J., 9: 201-206

Peralta, J.R., J.L. Gardea-Torresdey, K.J. Tiemann, E. Gomes, S. Arteaga, E. Rascon and J.G. Parsons, 2001. Uptake and effects of five heavy metals on seed germination and plant growth in alfalfa (Medicago sativa). Bull. Environ. Contam. Toxicol., 66: 727-734

Pinot, F., S. Kreps, M. Bachelet, P. Hainaut, M. Bakonyi and B. Polla, 2000. Cadmium in the environment: sources, mechanisms of biotoxicity, and biomarkers. Rev. Environ. Health, 15: 299-323

Pinto, A.P., A.M. Mota, A. De Varennes and F.C. Pinto, 2004. Influence of organic matter on the uptake of cadmium, zinc, copper and iron by sorghum plants. Sci. Total Environ., 326: 239-47

Prasad, M.N.V., 2004. Phytoremediation of metals in the environment for sustainable development, Proc. Indian Natn. Sci. Acad., 70: 71-98

Quartacci, M.F., A.J.M. Baker and F. Navari-Izzo, 2005. Nitrilotriacetateand citric acid-assisted phytoextraction of cadmium by Indian mustard (Brassica juncea (L.) Czernj, Brassicaceae). Chemosphere, 59: $1249-1255$ 
Rahman, M.S., N.K. Sana, M.M. Hasan, M.E. Huque and R.K. Shaha, 2008. Enzyme activities and degradation of nutrients in chickpea (Cicer arietinum L.) seeds during germination. J. Bio. Sci., 16: 29-34

Rahoui, S., A. Chaoui and E. El Ferjani, 2010. Membrane damage and solute leakage from germinating pea seed under cadmium stress. $J$. Hazard Mater, 15: 1-3

Ramon, O., E. Vazquez, M. Fernandez, M. Felipe and P. Zornoza, 2003. Cadmium stress in white lupine: effects on nodule structure and functioning. Plant Physiol., 161: 911-919

Riazi, A., K. Matruda and A. Arslan, 1985. Water-stress induced changes in concentrations of proline and other solutes in growing regions of young barley leaves. J. Exp. Bot., 36: 1716-1725

Roberts, I.N., P. F. Murray, C.P. Caputo, S. Passeron and A.J. Barneix, 2003. Purification and characterization of a subtilisin-like serine protease induced during the senescence of wheat leaves. Physiol. Plant., 118: 483-490

Romkens, P., L. Bouwman, J. Japenga and C. Draaisma, 2002. Potentials and drawbacks of chelate-enhanced phytoremediation of soils. Environ. Pollut., 116: 109-121

Russak, J.M., K. Kabala, M. Burzynski and G. Klobus, 2008. Response of plasma membrane $\mathrm{H}^{+}$-ATPase to heavy metal stress in Cucumis sativus roots. J. Exp. Bot., 59: 3721-3728

Sadiq, R., 2014. Effect of natural and synthetic chelators on phytoextraction of cadmium (Cd) by sunflower (Helianthus annuus L.). Ph.D. Thesis, Department of Botany, University of Agriculture, Faisalabad, Pakistan

Saifullah, M.E., M. Qadir, P. de Caritat, F.M.G. Tack, G.D. Du Laing and M.H. Zia, 2009. EDTA-assisted Pb phytoextraction. Chemosphere, 74: 1279-1291

Segarra, C.I., C.A. Casalongue, M.L. Pinedo, C.A. Cordo and R.D. Conde, 2002. Changes in wheat leaf extracellular proteolytic activity after infection with Septoria tritici. J. Phytopathology, 150: 105-111

Sethy, S.K. and S. Ghosh, 2013. Effect of heavy metals on germinating of seeds. J. Nat. Sci. Biol. Med., 4: 272-275

Sfaxi-Bousbih, A., A. Chaoui and E. El-Ferjani, 2010. Cadmium impairs mineral and carbohydrate mobilization during the germination of bean seeds. Ecotoxicol. Environ. Saf., 73: 1123-1129

Shafiq, M., I.M. Zafar and M. Athar, 2008. Effect of lead and cadmium on germination and seedling growth of Leucaena leucocephala. J. Appl. Sci. Environ. Manage., 12: 61-66

Singh, P.K. and R.K. Tewari, 2003. Cadmium toxicity induced changes in plant water relations and oxidative metabolism of Brassica juncea $\mathrm{L}$ plants. J. Environ. Biol., 24: 107-112

Smiri, M., 2011. Effect of cadmium on germination, growth, redox and oxidative properties in Pisum sativum seeds. J. Environ. Chem. Ecotocicol., 3: 52-59

Sreenivasulu, N., B. Usadel, A. Winter, V. Radchuk, U. Scholz, N. Stein, W. Weschke, M. Strickert, T.J. Close and M. Stitt, 2008. Barley grain maturation and germination: metabolic pathway and regulatory network commonalities and differences highlighted by new MapMan/ PageMan profiling tools. Plant Physiol., 146: 1738-1758

Steel, R.G.D. and J.H. Torrie, 1986. Principles and Procedures of Statistics, pp: 336-354, $2^{\text {nd }}$ edition. Mc-Graw Hill Book Co., New York, USA

Subedi, C.K. and T. Bhattarai, 2003. Effect of gibberellic acid on reserve food mobilization of miaze (Zea mays L. var Arun-2) endosperm during germination. Himalayan J. Sci., 1: 99-102
Sun, Y., Q. Zhou, L. Wang and W. Liu, 2009. The Influence of different growth stages and dosage of EDTA on Cd uptake and accumulation in Cd hyperaccumulator (Solanum Nigrum L.). Bull. Environ. Contam. Toxicol., 82: 348-353

Taran, S.A., D.M. Baloch, N.U. Khan, J. Bakht, S.H. Ghaloo, N. Shahwani and M.S. Kakar, 2013. Earliness and yield performance of sunflower hybrids in uplands of Balochistan, Pakistan. Pak. J. Bot., 45 1397-1402

Veer, B., 1989. Effect of nickel and zinc on seedling growth and hydrolytic enzymes in Phaseolus aureus cv. R-851. Geobios, 16: 245-248

Vijayaragavan, M., C. Prabhahar, J. Sureshkumar, A. Natarajan, P. Vijayaragavan and S. Sharavanan, 2011. Toxic effect of cadmium on seed germination, growth and biochemical contents of cowpea (Vigna unguiculata L.) plants. Int. Multidis. Res. J., 1: 1-6

Wahid, A. and A. Ghani, 2008. Varietal differences in mungbean (Vigna radiata) for growth, yield, toxicity symptoms and cadmium accumulation. Ann. Appl. Biol., 152: 59-69

Wang, J., Y. Li, S.W. Lo, S. Hillmer, S.S.M. Sun, D.G. Robinson and L. Jiang, 2007. Protein mobilization in germinating mung bean seeds involves vacuolar sorting receptors and multivesicular bodies. Plant Physiol., 143: 1628-1639

Wei, B. and L. Yang, 2010. A review of heavy metal contaminations in urban soils, urban road dusts and agricultural soils from China. Microchem. J., 94: 99-107

Wu, F.B., F.K. Chen, K.G. Wei and P. Zhang, 2004. Effects of cadmium on free amino acids, glutathione and ascorbic acid concentration in two barley genotypes (Hordeum vulgare L.) differing in cadmium tolerance. Chemosphere, 57: 447-454

Yamauchi, D., 2003. Regulation of gene expression of a cysteine proteinase, EP-C1, by a VIVIPAROUS1-like factor from common bean. Plant Cell Physiol., 44: 649-652

Yang, J., J. Zhang, Z. Wang and Q. Zhu, 2001. Activities of starch hydrolytic enzymes and sucrose-phosphate synthase in the stems of rice subjected to water stress during grain filling. J. Exp. Bot., 52: 2169-2179

Yaylal1-Abanuz, G., 2011. Heavy metal contamination of surface soil around Gebze industrial area, Turkey. Microchem. J., 99: 82-92

Zeid, I.M., 2001. Responses of Phaseolus vulgaris to chromium and cobalt treatments. Biol. Plant., 44: 111-115

Zeremski-Skoric, T.M., P.D. Sekulic, I.V. Maksimovic, S.I. Seremesic, J.M. Ninkov, S.B. Milic and J.R. Vasin, 2010. Chelate-assisted phytoextraction: effect of EDTA and EDDS on copper uptake by Brassica napus L. J. Serb. Chem. Soc., 75: 1279-1289

Zhang, X.X., L. Chunjie and N. Zhibiao, 2012. Effects of cadmium stress on seed germination and seedling growth of Elymus dahuricus infected with the Neotyphodium endophyte. Sci. Chin. Life Sci., 55: 793-799

Zhu, Z.P., C.M. Hylton, U. Rossner and A.M. Smith, 1998. Characterization of starch debranching enzymes in pea embryos. Plant Physiol., 118 $581-590$

Zhuang, P., Z.H. Ye, C.Y. Lan, Z.W. Xie and W.S. Shu, 2005. Chemically assisted phytoextraction of heavy metal contaminated soils using three plant species. Plant Soil, 276: 153-162

(Received 29 January 2015; Accepted 14 May 2015) 